\title{
KONSISTENSI SISWA DALAM PEMECAHAN MASALAH FISIKA UNTUK URUTAN PERTANYAAN TERMODIFIKASI
}

\author{
Lili Handayani, Yusuf Kendek dan Jusman Mansyur \\ lilimunif@gmail.com \\ Program Studi Pendidikan Fisika FKIP Universitas Tadulako \\ Jl. Soekarno Hatta Km. 9 Kampus Bumi Tadulako Tondo Palu - Sulawesi Tengah
}

\begin{abstract}
Penelitian ini bertujuan untuk mendeskripsikan tentang konsistensi siswa dalam pemecahan masalah fisika untuk urutan pertanyaan termodifikasi. Penelitian ini dilakukan pada salah satu SMA Swasta di Kota Palu. Subyek penelitian pada siswa kelas XII C yang terdiri 30 siswa. Data diperoleh melalui lembar jawaban siswa, rekaman thinking-aloud dan wawancara. Pemberian TSR terdiri atas 20 butir untuk menentukan responden empat orang. Tes pemecahan masalah terdiri atas 4 butir yang dikerjakan responden sebanyak dua kali. Satu kali melalui aktivitas thinking-aloud. Data penelitian dianalisis melalui pendekatan deskriptif-kualitatif dengan merujuk pada tahapan pemecahan masalah menurut Polya. Hasil penelitian menunjukkan bahwa konsisten siswa dalam pemecahan masalah fisika untuk urutan pertanyaan termodifikasi sangatlah kurang. Pengaruhnya menyebabkan tahap-tahap penyelesaian untuk memecahkan masalah fisika yang dimiliki oleh siswa masih kurang. Baik dari segi memahami permasalahan, merencanakan pemecahan masalah, melaksanakan pemecahan masalah dan mengecek kembali pemecahan masalah.
\end{abstract}

Kata Kunci : konsistensi, pemecahan masalah fisika, urutan pertanyaan termodifikasi

\section{PENDAHULUAN}

Mata pelajaran fisika merupakan salah satu mata pelajaran pokok yang kebanyakan siswa menganggap sulit bahkan cenderung membosankan. Pelajaran fisika yang banyak menggunakan rumus-rumus dan perhitungan membuat kurangnya minat siswa pada fisika. Sesungguhnya dalam mata pelajaran fisika dapat menerapkan pembelajaran yang menekankan pada konsep agar siswa lebih mudah memahami ${ }^{[1]}$.

Dalam sebuah buku ${ }^{[2]}$ yang berjudul "how solve it" dituliskan bahwa pemecahan masalah sebagai satu usaha mencari jalan keluar dari satu kesulitan guna mencapai satu tujuan yang tidak begitu mudah segera untuk dicapai. Secara rinci bagaimana suatu permasalahan khususnya permasalahan yang bersifat matematis. Secara garis besar dia mengemukakan tahap-tahap pemecahan masalah yaitu:

(1). Memahami permasalahan

(2). Merencanakan pemecahan masalah

(3). Melaksanakan pemecahan masalah (solusi) berdasarkan rencana, dan

(4). Memeriksa kembali hasil pemecahan masalah (solusi) dan mendiskusikannya.

Beberapa penelitian yang dilakukan sebelumnya $^{[3]}$ terungkap bahwa kemampuan memecahkan masalah masih sangat rendah. Apalagi bila siswa tersebut belum menguasai konsep secara matang. Hal ini dapat mengakibatkan ketidakkonsistensian siswa dalam memecahkan masalah walaupun dalam masalah tersebut memiliki konsep yang sama. Berdasarkan suatu studi bahwa siswa sering menggunakan model konseptual mereka secara tidak konsisten ketika memecahkan beberapa pertanyaan yang menguji ide yang sama.

Pertanyaan merupakan salah satu instrumen yang digunakan dalam penelitian. Oleh sebab itu, pertanyaan haruslah memiliki struktur agar dapat digunakan untuk mengetahui pola berpikir siswa. Sebuah penelitian yang dilakukan pada mahasiswa semester pertama di Universitas Cambridge, Cavendish Laboratory mengenai pengaruh penggunaan struktur pertanyaan terhadap kemampuan pemecahan masalah fisika. Struktur pertanyaan dibuat menjadi dua jenis yakni pertanyaan model universitas dan pertanyaan model scaffolding. Hasilnya menunjukan bahwa bentuk pertanyaan scaffolding dapat memperbaiki kemampuan pemecahan masalah karena sebelumnya mahasiswa memiliki kesalahan matetatika pada pemecahan masalah fisika ${ }^{[4]}$.

Salah satu penelitian yang meyerupai dilakukan, yang hasilnya menunjukan jika seorang siswa menjawab pertanyaanpertanyaan secara konsisten dengan benar maka ia harus mampu menjawab dengan benar semua pertanyaan yang berhubungan dengan konsep yang sama ${ }^{[3]}$. Penelitian lain yang 
mengenai konsistensi dengan mengembangkan metode yang melibatkan analisis urutan pertanyaan. Ia menyimpulkan bahwa terdapat ketidakkonsistenan siswa dalam penalaran untuk memecahkan masalah fisika hal ini dilihat dari proses penalaran siswa dalam menyelesaikan pertanyaan-pertanyaan yang saling berkaitan yang menunjukan bahwa siswa juga mengalami kesulitan dan kekurangan dalam pemahaman konseptual ${ }^{[5]}$.

Pernyataan ini mendorong peneliti untuk menyelidiki kosistensi siswa dalam memecahkan masalah fisika untuk urutan pertanyaan yang termodifikasi pada konsep fluida dinamik. Penelitian dilakukan dengan menggunakan struktur pertanyaan yang berbeda yakni bentuk soal terikat dan soal tidak terikat. Penggunaan struktur pertanyaan inilah yang membedakan dengan penelitian lainnya. Pemberian tes diberikan sebanyak dua kali dengan struktur pertanyaan yang berbedaan yang dilaksanakan dengan prosedur tes untuk thingking aloud.

\section{METODE PENELITIAN}

Penelitian ini menggunakan pendekatan deskriptif-kualitatif yang datanya berupa faktafakta yang ada. Subyek dalam penelitian ini adalah 30 siswa SMA Kelas XII C di sebuah sekolah di Kota Palu Tahun Ajaran 2015/2016. Responden dalam penelitian ini sebanyak 4 (empat) orang siswa berdasarkan skor tes seleksi responden (TSR) untuk mengerjakan tes untuk thinking-aloud (TA) dalam memecahkan permasalahan fisika dan terlibat dalam sesi wawancara.

TSR sebanyak 20 butir soal diberikan kepada 30 siswa. Data dari hasil TSR, dihitung skor rata-rata dan standar deviasi. Skor tersebut dikelompokkan berdasarkan kategori tinggi, sedang dan rendah. Responden yang terpilih diberi tes thinking-aloud sebanyak 4 butir soal yang memiliki dua jenis soal yakni soal terikat dan soal tidak terikat. Konteks soal berisi materi fluida dinamik. Tes TA diberikan sebanyak dua kali dengan perbedaan soal pada urutannya yang telah dimodifikasi. Hasil lembar jawabannya dibandingkan antara urutan pada tes TA-I dan tes TA-II untuk melihat konsistensi siswa. Proses pemecahan masalah yang digunakan dianalisis dengan merujuk pada tahap pemecahan masalah menurut Polya ${ }^{[2]}$.

Hasil pengelolaan data, skor rata-rata yang diperoleh adalah 31,33 dan nilai standar deviasi adalah 14,80. Berdasarkan skor rata- rata dan standar deviasi tersebut, Responden yang terpilih untuk terlibat thinking-aloud dan wawancara berdasarkan kategori disajikan pada Tabel 1.

Tabel 1 Kode dan Kategori Responden

\begin{tabular}{|c|c|c|}
\hline No & $\begin{array}{c}\text { Inisial } \\
\text { Responden }\end{array}$ & Kategori \\
\hline 1 & R-30 & Tinggi \\
\hline 2 & R-29 & Tinggi \\
\hline 3 & R-19 & Sedang \\
\hline 4 & R-03 & Rendah \\
\hline
\end{tabular}

Tes disusun dengan struktur pertanyaan yang berbeda sehingga menghasilkan dua tipe tes yaitu tes untuk TA-I yang asli dan tes untuk TA-II yang dimodifikasi urutan pertanyaannya. Hal ini dilakukan agar dapat lebih jelas penggambaran sikap konsistensi responden dalam memecahkan masalah fisika. Berikut ini susunan urutan pertanyaan pada kedua tes pada Tabel 2 .

Tabel 2 Korelasi urutan pertanyaan tes TA

\begin{tabular}{|c|c|c|}
\hline \multirow{2}{*}{$\begin{array}{c}\text { Somor } \\
\text { Soal }\end{array}$} & \multicolumn{2}{|c|}{ Urutan Pertanyaan Soal } \\
\cline { 2 - 3 } & Tes TA-I & Tes TA-II \\
\hline 1 & a b c & a c b \\
\hline 2 & a b c & c a b \\
\hline 3 & b a & a b \\
\hline 4 & a b c & b a c \\
\hline
\end{tabular}

\section{HASIL PENELITIAN DAN PEMBAHASAN.}

Topik utama penelitian menitikberatkan pada gambaran konsistensi siswa pada urutan jawaban tes TA-I dan tes TA-II dalam problem solving. Dalam hal konsistensi siswa untuk urutan pertanyaan, peneliti tidak melihat aspek kebenaran atau kesalahan jawaban dari responden pada pengerjaan tes untuk TA. Peneliti hanya mengungkapkan dan mendeskripsikan dari segi konsistensi siswa pada urutan jawaban TA-I dan TA-II dalam problem solving. Penentuan peneliti kepada siswa yang konsistens pada urutan jawaban TA-I dan TA-II dalam problem solving bukan menunjukkan bahwa siswa tersebut dianggap benar dalam problem solving. Sebaliknya sikap tidak konsisten bukan berarti menunjukkan siswa tersebut salah. Cara siswa menjawabnya berdasarkan urutan pertanyaan yang ada di kedua soal tersebut yang dapat menggambarkan karakteristik siswa dalam memecahkan masalah fisika yang dapat dikatakan konsistensi untuk urutan pertanyaan termodifikasi. Setelah itu proses pemecahan masalahnya dianalisis berdasarkan tahapan yang dikemukakkan oleh Polya ${ }^{[2]}$. 


\section{> Responden dengan TSR Kategori Tinggi}

Responden dengan kategori tinggi yakni R-30 mampu mengerjakan soal pada TA-I dan TA-II. Hasilnya menunjukkan bahwa R-30 konsisten pada soal Nomor 3 dan Nomor 4 dan tidak konsisten pada soal Nomor 1 dan soal Nomor 2.

Hasil penelitian yang dilakukan pada bentuk soal terikat dan soal tidak terikat. Terlihat siswa banyak mengalami kesalahan pada soal mengenai gaya angkat pesawat. Kesalahan yang dilakukan pada penggunaan persamaan yang tidak tepat.

Pada soal mengenai gaya angkat pesawat pada tes untuk TA-I dan TA-II yang dilakukan oleh R-30 dapat dikatakan konsisten dari segi cara menjawab berdasarkan urutan pertanyaan termodifikasi. Urutan jawaban ditunjukan pada potongan lembar jawaban pada Gambar 1 dan Gambar 2.

Proses pemecahan masalah pada TA-I dan TA-II yang dilakukan oleh R-30 adalah salah. Kesalahan ini disebabkan persamaan yang digunakan oleh R-30 tidak tepat. Kesalahan yang dibuat oleh $\mathrm{R}-30$ diakuinya karena ia tidak memahami konsep. R-30 juga mengaku bahwa soal mengenai gaya angkat pesawat sangat jarang ditemui atau diberikan ketika mata pelajaran.



Gambar 1 Kutipan jawaban R-30 No.3 tentang gaya angkat pesawat pada TA-I

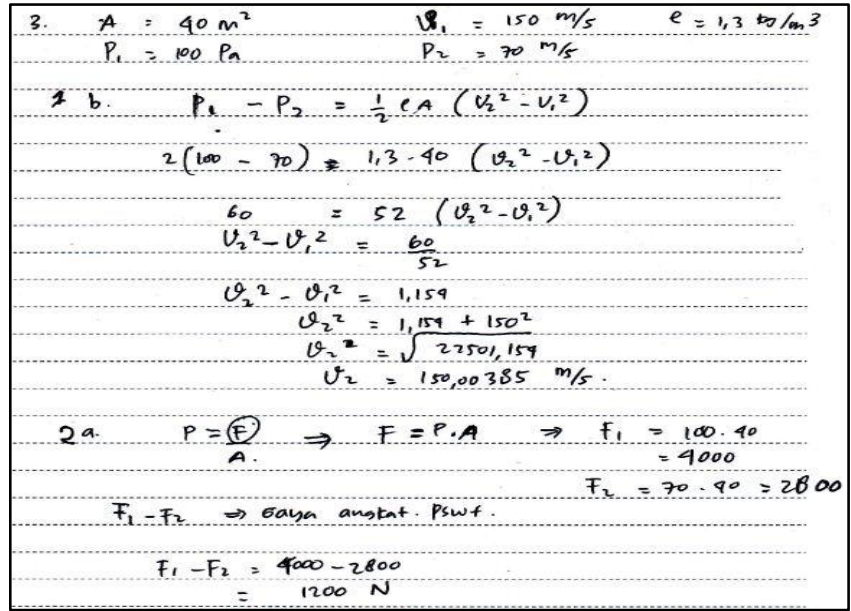

Gambar 2 Kutipan jawaban R-30 No.3 tentang gaya angkat pesawat pada TA-II

Proses pemecahan masalah yang lakukan oleh R-30 telihat tidak tepat pada rekaman untuk TA yang dilakukan pada saat mengerjekan soal. Terlihat jelas bahwa R-30 tidak menguasai soal bahkan tidak memahami konsepn. Berikut hasil rekaman TA R-30 pada TA-II yang menunjukkan cara menyelesaikan soal.

Potongan transkip TA-II

\{---\}bagian b). dimana persamaan Bernoulli $P_{1}-P_{2}=\frac{1}{2} \rho A\left(v_{2}^{2}-v_{1}^{2}\right)$ berarti $2(100-70)=1,3$ dikali $40\left(v_{2}^{2}-v_{1}^{2}\right)$ sama dengan 60 sama dengan $52\left(v_{2}^{2}-v_{1}^{2}\right)$ maka $\left(v_{2}^{2}-v_{1}^{2}\right)$ sama dengan 60 dibagi 52 jadi $\left(v_{2}^{2}-v_{1}^{2}\right)$ sama dengan $\{--\} 1,154$ , maka $v_{2}^{2}$ sama dengan 1,154 ditambah $150^{2}, v_{2}$ sama dengan akar $\{--\} 22501,154$ maka $v_{2}$ sama dengan $150,00385 \mathrm{~m} / \mathrm{s}\{---\}$ bagian a). gaya angkat pesawat untuk $F_{1}=100$ dikali 40 sama dengan 4000 dan $F_{2}=70$ dikali 40 sama dengan 2800 maka gaya angkat pesawat $F_{1}-F_{2}$ sama dengan 4000 dikurang 2800 sama dengan 1200 Newton.

Kesalahan dalam penggunaan persamaan ini dapat diperkuat dengan informasi yang diperoleh berdasarkan hasil wawancara untuk soal Nomor 3. Berikut ini hasil wawancara terhadap R-30.

$P \quad$ : Soal nomor 3 itu bagian mana yang tidak paham?

$R-30$ : Di bagian yang gaya angkat pesawat, saya bingung persamaannya yang mana, kalau konsepnya pesawat take off kecepatan yang diatas harus lebih besar dari pada yang dibawah jadi gayanya itu saya bingung.

Penggunaan persamaan yang tidak tepat menyebabkan hasil jawaban siswa tidak benar. Walaupun siswa menjawab soal dengan konsisten hanya karena proses pemecahan masalah yang tidak tepat sehingga jawabannya menjadi salah. 
Responden dengan kategori tinggi lainnya adalah R-29. Hasil jawaban menunjukan bahwa dari empat soal tidak ada yang konsisten. Proses pemecahan masalah yang dilakukan telihat beberapa persamaan yang digunakan tidak tepat untuk menyelesaikan soal.

Salah satu soal yang dikerjakan R-29 tidak konsisten dalam menjawab soal mengenai gaya angkat pesawat pada TA-I dan TA-II berdasarkan urutan pertanyaan termodifikasi. Urutan jawaban ditunjukan pada potongan lembar jawaban pada Gambar 3 dan Gambar 4.

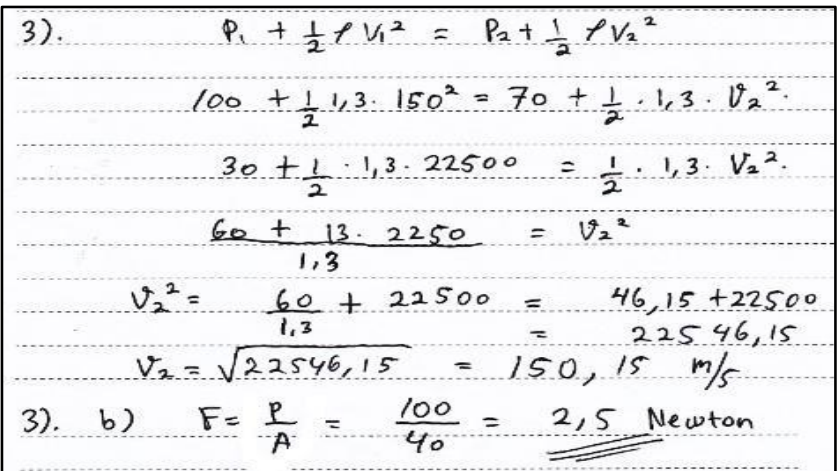

Gambar 3 Kutipan jawaban R-29 No.3 tentang gaya angkat pesawat pada TA-I

\begin{tabular}{|c|}
\hline 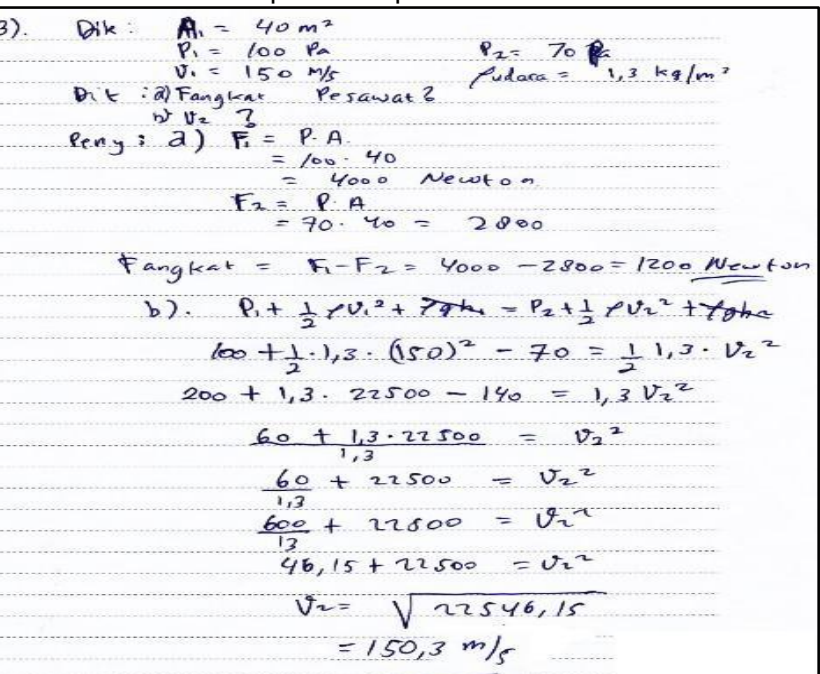 \\
\hline
\end{tabular}

Gambar 4 Kutipan jawaban R-29 No.3 tentang gaya angkat pesawat pada TA-II

Ketidakkonsistenan urutan jawaban R-29 menyebabkan pada TA-I, ia menggunakan persamaan yang tidak tepat untuk mencari kecepatan aliran udara dan menggunakan persamaan yang salah untuk mencari gaya angkat pesawat. Pada TA-II kesalahan dilakukan kembali pada penyelesaian untuk mencari kecepatan aliran udara. Hal ini juga terlihat pada potongan transkip TA

$\{---\}$ sekarang untuk kecepatan $v_{2}$ ada persamaan Bernoulli itu $P_{1}$ tambah $1 / 2 \rho v_{1}^{2}$ tambah $\rho g h_{1}$ sama dengan $P_{2}$ tambah $1 / 2 \rho v_{2}^{2}$ tambah $\rho g h_{2}$ kan h-nya tidak berpengaruh, ketinggian [dicoret] sekarang tujuannya adalah mencari $v_{2}$ jadi disini $P_{1}$ nya 100 ditambah $1 / 2$ dikali 1,2 dikali 150 kuadrat dikurang 70 ini yang $\mathrm{P}_{2}$ langsung saya pindah ruaskan sama dengan $1 / 2$ dikali 1,3 dikali $v_{2}^{2}$ terus supaya duanya hilang saya kalikan 2 semua 200 ditambah 1,3 dikali 150 kuadrat itukan 22500 dikurang 140 sama dengan $1,3 v_{2}{ }^{2}$. Ini kurang jadi 60 ditambah 1,3 kali 22500 per 1,3 sama dengan $v_{2}{ }^{2}$. ini 60 per 1,3 ditambah 22500 sama dengan $v_{2}^{2}\{---\}$ 46,15 ditambah 22500 sama dengan $v_{2}{ }^{2}$ dijumlahkan $v_{2}$ sama dengan akar 22546,15 sama dengan 150,15 m/s didapat kecepatan aliran udaranya $\{--\}$

Mengenai gaya angkat pesawat, R-29 mengakui bahwa mengalami kesulitan karena tidak dapat mengingat persamaan yang seharusnya digunakan. Untuk jawaban TA-I hasilnya salah. Hal ini juga diperkuat dengan pengakuan R-29 pada wawancara yang menyatakan bahwa ia sudah tidak dapat menemukan cara untuk menyelesaikan soal. Oleh sebab itu, R-29 melakukan pemecahan masalah untuk gaya angkat pesawat dengan persamaan yang tidak tepat. Proses pemecahan masalah yang lakukan oleh R-29 terlihat bahwa persamaan yang digunakan tidak tepat. Artinya R-29 tidak melakukan perencanaan pemecahan masalah dengan benar yang menyebabkan kesalahan analisis dalam menggunakan persamaan. Penyelesaian masalah juga tidak dilakukan secara sistematis yang menyebabkan hasilnya keliru. Kurangnya pengecekan kembali jawaban juga menjadi salah satu penyebab jawaban salah.

Selain itu, R-29 juga mengakui bahwa untuk soal gaya angkat pesawat menurutnya sedikit sulit dikerjakan. Oleh karena itu, R-29 mengerjakan soal gaya angkat pesawat dengan konsep dasar mengenai teorema Torricelli yang diketahuinya yakni mengenai persamaan Bernoulli seperti yang ditunjukan pada lembar jawaban.

\section{Responden dengan TSR Kategori Sedang}

Responden dengan kategori sedang adalah R-19. Hasil jawaban menunjukan bahwa dari empat soal tidak ada yang konsisten. Proses pemecahan masalah yang dilakukan telihat beberapa persamaan yang digunakan tidak tepat untuk menyelesaikan soal. R-19 mengakui bahwa dari empat soal yang dikerjakan soal mengenai gaya angkat pesawat yang dianggap susah karena jarang ditemui. Selain itu, kurangnya pemahaman konsep mengenai gaya angkat pesawat pun membuat 
R-19 mengerjakan soal dengan menggunakan persamaan yang tidak tepat.

Soal mengenai gaya angkat pesawat jawaban R-19 pada TA-I dan TA-II menunjukkan bahwa R-19 tidak konsisten pada urutan jawaban pertanyaan termodifikasi. Urutan jawaban ditunjukan pada potongan lembar jawaban pada Gambar 5 dan Gambar 6.

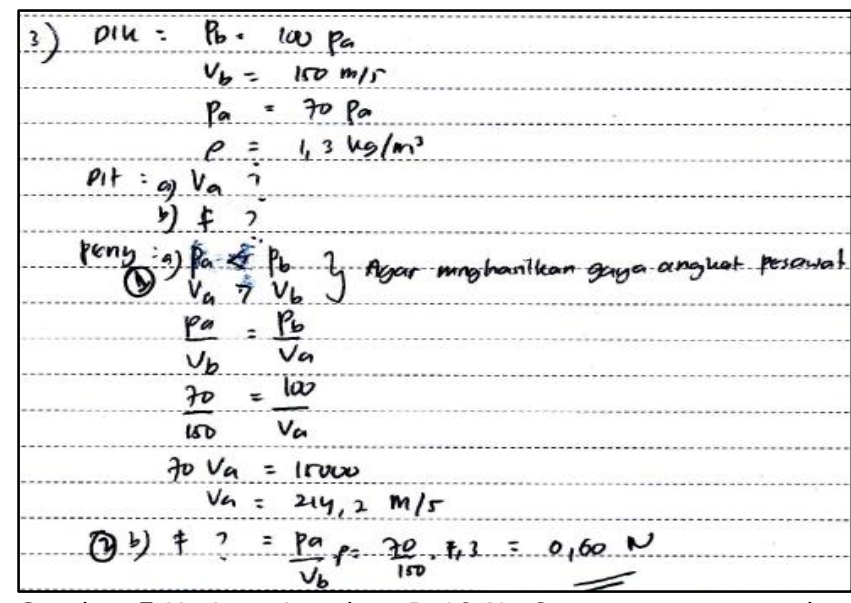

Gambar 5 Kutipan jawaban R-19 No.3 tentang gaya angkat pesawat pada TA-I

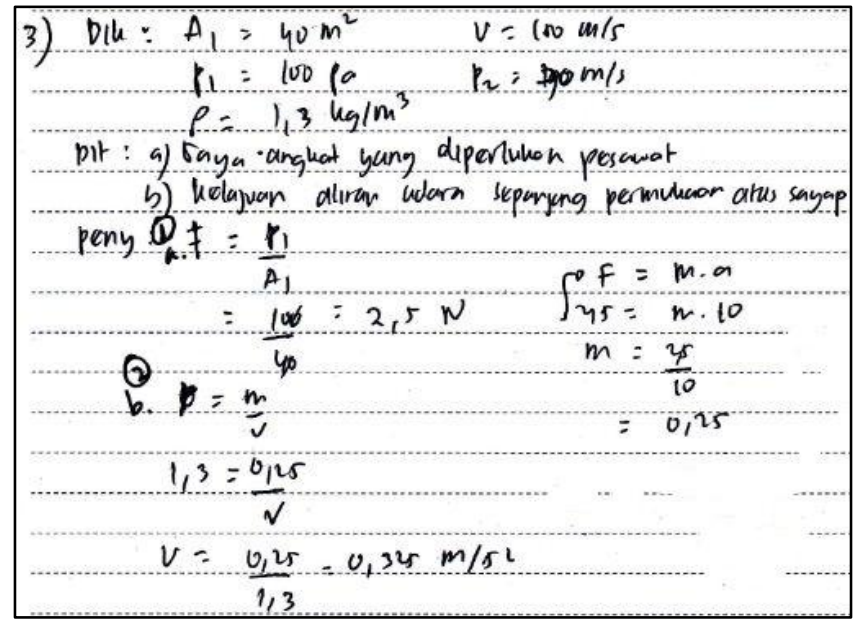

Gambar 6 Kutipan jawaban R-19 No.3 tentang gaya angkat pesawat pada TA-II

Pemahaman tentang materi gaya angkat pesawat yang dimiliki R-19 sangat kurang menyebabkan pemecahan masalah yang dilakukan salah. Tahap yang dilakukan dalam memecahkan masalah juga terlihat tidak melakukan tahap merencanakan pemecahan masalah, melaksanakan pemecahan masalah dan mengecek kembali pemecahan masalah sesuai dengan ciri tahapan yang dikemukakan oleh Polya. ${ }^{[2]}$ Oleh karena itu, R-19 tidak dapat menyelesaikan soal Nomor 3 dengan jawaban yang benar.

\section{Responden dengan TSR Kategori Rendah}

Responden dengan kategori rendah adalah R-03 mampu menyelesaikan kedua soal pada TA-I dan TA-II. Namun, dilihat dari jawaban R-03 tidak ada jawaban yang benar. Hal ini karena, R-03 tidak menggunakaan persamaan yang tepat untuk memecahkan masalah. Berdasarkan urutan cara menjawab pada TA-I dan TA-II, R-03 konsisten pada soal Nomor 1 dan Nomor 3 dan tidak konsisten pada soal Nomor 2 dan Nomor 4. Keempat soal yang diberikan memiliki dua tipe yang berbeda yakni soal terikat dan tidak terikat. Hasilnya menunjukkan bahwa R-03 konsisten pada soal terikat dan tidak konsisten pada soal tidak terikat.

Salah satu soal mengenai gaya angkat pesawat yang merupakan soal terikat ini mampu dijawab R-03 dengan konsisten. Hal ini ditunjukkan pada lembar jawaban R-03 pada TA-I dan TA-II. Urutan jawaban ditunjukan pada potongan lembar jawaban pada Gambar 7 dan Gambar 8.

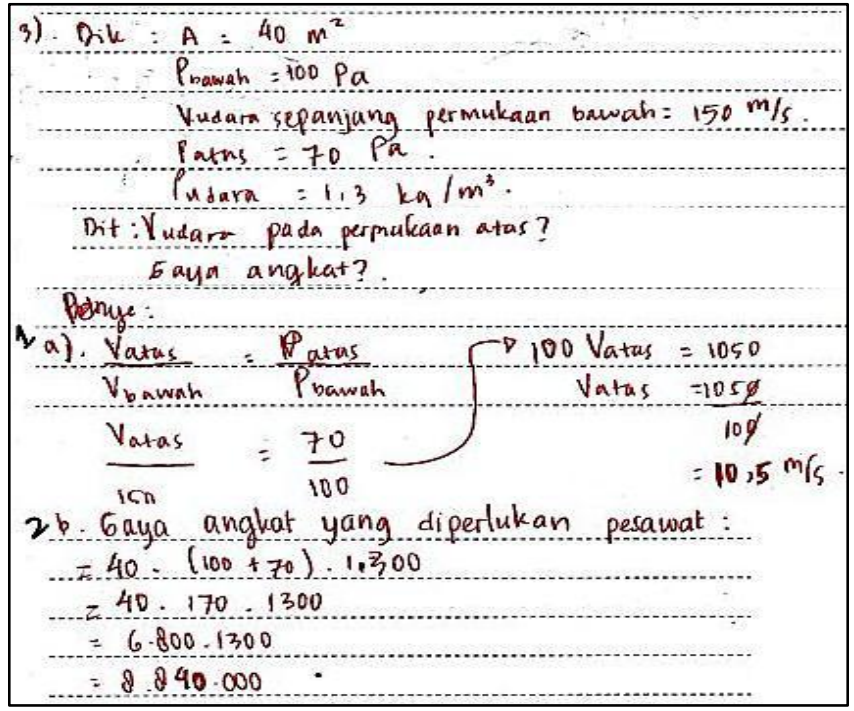

Gambar 7 Kutipan jawaban R-03 No.3 tentang gaya angkat pesawat pada $\mathrm{TA}-\mathrm{I}$ 


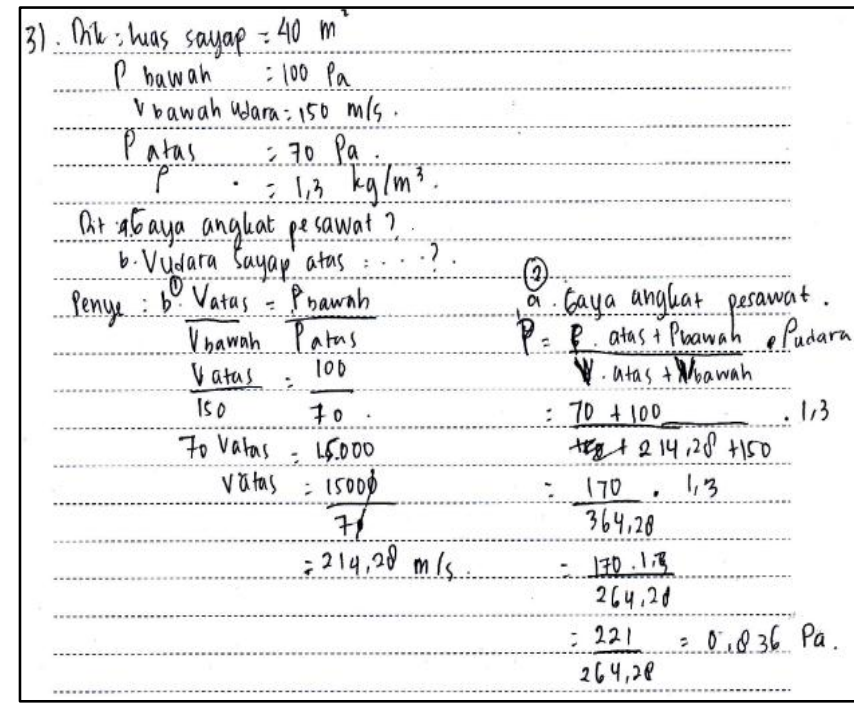

Gambar 8 Kutipan jawaban R-03 No.3 tentang gaya angkat pesawat pada TA-II

Berdasarkan lembar jawaban diketahui bahwa R-03 tidak melakukan beberapa tahapan yang dikemukan Polya. ${ }^{[2]}$ Tahapan yang tidak dilakukan yakni kurangnya memahami permasalahan pada soal yang menyebabkan R-03 tidak dapat menentukan persamaan yang tepat. Artinya, ia tidak dapat merencanakan dan melaksanakan pemecahan masalah dengan benar. Selain itu, adanya kekeliruan dalam penulihan hasil perhitungan juga memperkuat anggapan bahwa R-03 tidak melakukan pengecekan kembali pada jawabannya sehingga hasilnya salah.

Faktor penyebab R-03 tidak megikuti mata pelajaran fisika pada kelas XI khususnya pada materi fluida dinamik membuat R-03 tidak mengetahui konsepnya. Bahkan untuk simbol gaya angkat pesawat pun R-03 tidak diketahuinya. Hal ini terlihat dengan jelas pada jawaban R-03 mengenai simbol gaya angkat pesawat pada TA-I, R-03 bahkan tidak memberikan simbol apapun sedangkan pada TA-II R-03 memberikan simbol namun simbol yang digunakan salah. Hal ini diperjelas dengan hasil rekaman TA pada soal Nomor 3 yang dilakukan oleh R-03.

Penelitian yang dilakukan pada empat responden dari tiga kelompok kategori yakni kategori tinggi R-30 dan R-29, kategori sedang R-19 dan kategori rendah R-03. Hasilnya menunjukkan konsistensi responden untuk urutan pertanyaan termodifikasi dari TA-I dan TA-II bebeda-beda. Pada proses pemecahan masalah tahap-tahapan dalam menyelesaian masalah fisika berbeda dari masing-masing siswa. Empat responden yang ada dua responden tidak konsisten pada semua soal yaitu R-29 dan R-19. Responden R-29 tidak konsisten untuk urutan jawaban pertanyaan dengan alasan bahwa jika mengerjakan secara acak akan membuatnya lebih bingung. Pada R-19 tidak konsisten di semua soal karena ia mengerjakan soal berdasarkan yang diketahui. Jika soal bisa dikerjakan dengan data-data yang sudah ada maka akan segera diselesaikan pemecahan masalahnya. Dua responden lainnya yakni R-30 konsisten untuk urutan pertanyaan termodifikasi pada TA-I dan TA-II pada soal Nomor 3 dan Nomor 4 sedangkan R03 konsisten pada soal Nomor 1 dan Nomor 3.

Hubungan konsistensi responden dalam menjawab pertanyaan berdasarkan urutan pertanyaan juga dapat mempengaruhi proses pemecahan masalah yang dilakukan oleh responden. Pengaruh konsistensi atau ketidakkonsistensian pada urutan jawaban pertanyaan termodifikasi dapat memepengaruhi proses pemecahan masalah yang siswa lakukan disajikan pada tabel 3.

Tabel 3 Hubungan antara konsistensi urutan pertanyaan dan pemecahan masalah

\begin{tabular}{|c|c|c|c|c|c|c|c|c|}
\hline \multirow{2}{*}{ Responden } & \multirow{2}{*}{$\begin{array}{l}\text { Nomor } \\
\text { soal }\end{array}$} & \multirow{2}{*}{$\begin{array}{l}\text { Konsistensi } \\
\text { Urutan } \\
\text { Pertanyaan }\end{array}$} & \multicolumn{4}{|c|}{$\begin{array}{l}\text { Pemecahan } \\
\text { masalah }\end{array}$} & \multicolumn{2}{|c|}{ Jawaban } \\
\hline & & & 1 & 2 & 3 & 4 & TA-I & TA-II \\
\hline \multirow{4}{*}{$R-30$} & 1 & Tidak Konsisten & - & $\sqrt{ }$ & $\sqrt{ }$ & - & Salah pada bagian debit & Benar \\
\hline & 2 & Tidak Konsisten & $\sqrt{ }$ & $\sqrt{ }$ & $\sqrt{ }$ & $\sqrt{ }$ & $\begin{array}{l}\text { Penggunaan persamaan tidak } \\
\text { tepat untuk mencari waktu }\end{array}$ & $\begin{array}{l}\text { Penggunaan persamaan tidak } \\
\text { tepat untuk mencari waktu }\end{array}$ \\
\hline & 3 & Konsisten & $\sqrt{ }$ & - & - & - & $\begin{array}{c}\text { Penggunaan persamaan tidak } \\
\text { tepat }\end{array}$ & $\begin{array}{c}\text { Persamaan kelajuan aliran } \\
\text { udara tidak tepat }\end{array}$ \\
\hline & 4 & Konsisten & $\sqrt{ }$ & $\sqrt{ }$ & - & - & $\begin{array}{l}\text { Persamaan untuk beda } \\
\text { ketinggian tidak tepat }\end{array}$ & Penyelesaian perhitungan salah \\
\hline \multirow{3}{*}{$R-29$} & 1 & Tidak Konsisten & $\sqrt{ }$ & $\sqrt{ }$ & $\sqrt{ }$ & $\sqrt{ }$ & Persaman benar & $\begin{array}{l}\text { Penggunaan persamaan untuk } \\
\text { mencari kecepatan air kurang } \\
\text { tepat }\end{array}$ \\
\hline & 2 & Tidak Konsisten & $\sqrt{ }$ & $\sqrt{ }$ & $\sqrt{ }$ & $\sqrt{ }$ & $\begin{array}{l}\text { Penggunaan persamaan tidak } \\
\text { tepat untuk mencari waktu }\end{array}$ & Persamaan benar \\
\hline & 3 & Tidak Konsisten & $\sqrt{ }$ & $\sqrt{ }$ & - & - & Persamaan tidak tepat & $\begin{array}{l}\text { Persamaan kurang tepat dan } \\
\text { penyelesaian perhitungan tidak }\end{array}$ \\
\hline
\end{tabular}




\begin{tabular}{|c|c|c|c|c|c|c|c|c|}
\hline & & & & & & & & sistematis \\
\hline & 4 & Tidak Konsisten & $\sqrt{ }$ & $\sqrt{ }$ & $\sqrt{ }$ & $\sqrt{ }$ & Persamaan kurang tepat & Persamaan kurang tepat \\
\hline \multirow{4}{*}{$\mathrm{R}-19$} & 1 & Tidak Konsisten & $\sqrt{ }$ & $\sqrt{ }$ & - & - & Konversi satuan salah & $\begin{array}{c}\text { Satuan salah dan persamaan } \\
\text { kurang tepat }\end{array}$ \\
\hline & 2 & Tidak Konsisten & $\sqrt{ }$ & $\sqrt{ }$ & $\sqrt{ }$ & - & $\begin{array}{l}\text { Penggunaan persamaan tidak } \\
\text { tepat untuk mencari waktu }\end{array}$ & $\begin{array}{l}\text { Penggunaan persamaan tidak } \\
\text { tepat untuk mencari waktu }\end{array}$ \\
\hline & 3 & Tidak Konsisten & $\sqrt{ }$ & - & - & - & Persamaan salah & Persamaan salah \\
\hline & 4 & Tidak Konsisten & $\sqrt{ }$ & $\sqrt{ }$ & - & - & $\begin{array}{l}\text { Persamaan untuk beda } \\
\text { ketinggian tidak tepat }\end{array}$ & $\begin{array}{l}\text { Persamaan untuk beda } \\
\text { ketinggian tidak tepat }\end{array}$ \\
\hline \multirow{4}{*}{$\mathrm{R}-03$} & 1 & Konsisten & - & - & - & - & $\begin{array}{c}\text { Persamaan kontuinitas tidak } \\
\text { tepat }\end{array}$ & Persamaan kurang tepat \\
\hline & 2 & Tidak Konsisten & - & - & - & - & Persamaan salah & Persamaan salah \\
\hline & 3 & Konsisten & - & - & - & - & Persamaan salah & Persamaan salah \\
\hline & 4 & Tidak Konsisten & - & - & - & - & Persamaan salah & Persamaan salah \\
\hline \multirow[b]{2}{*}{ Ket: } & $\begin{array}{l}1 \\
2\end{array}$ & \multicolumn{7}{|c|}{ : merencanakan pemecahan masalah } \\
\hline & $\begin{array}{l}3 \\
4\end{array}$ & \multicolumn{7}{|c|}{ : melaksanakan pemecahan masalah (solusi) berdasarkan rencana } \\
\hline
\end{tabular}

Hasil penelitian ini menunjukkan bahwa konsistensi siswa dalam pemecahan masalah fisika untuk urutan pertanyaan termodifikasi masih sangat kurang. Hal ini telihat bahwa responden lebih banyak tidak konsisten pada urutan pertanyaan termodifikasi. Selain itu, tahap pemecahan masalah yang dilakukan untuk tahap memahami permasalahan, merencanakan pemecahan masalah, melaksanakan pemecahan masalah dan mengecek kembali pemecahan masalah masih kurang.

Hasil penelitian ini sama dengan penelitian yang dilakukan oleh Prihastuti ${ }^{[1]}$ yang mengungkapkan bahwa sikap konsistensi antara pandangan dan perilaku untuk memecahkan masalah fisika yang dimiliki oleh siswa masih kurang, baik dari segi memahami penyelesaian, merencanakan penyelesaian, menerapkan penyelesaian dan mengecek kembali solusi penyelesaian.

Penggunaan sturuktur pertanyaan juga dapat mempengaruhi konsistensi siswa untuk urutan pertanyaan termodifikasi. Hal itu juga dapat mempengaruhi proses pemecahan masalah yang dilakukan siswa saat mengerjakan soal. Perbedaan jenis soal yang diberikan ternyata memeberika pengaruh terhadap konsistensi siswa dan pemecahan masalah pada soal. Penelitian ini menggunakan dua jenis soal yaitu soal terikat dan tidak terikat serta ada perbedaan urutan pertanyaan pada TA-I dan TA-II. Perbedaan jenis soal dan urutan pertanyaan tidak disadari oleh siswa sehingga dampak siswa banyak tidak konsisten dalam menjawab soal. Dampak pada proses pemecahan masalah karena adanya perbedaan urutan pertanyaan dan jenis soal yakni beberapa siswa mengerjakan soal menggunakan persamaan yang tidak tepat. Selain itu, siswa juga mengalami kebingungan ketika mengerjakan soal. Hasil penelitian ini berbeda dengan penelitian sebelumnya ${ }^{[4]}$ yang menyelidiki dampak atau pengaruh perbedaan struktur pertanyaan pada mahasiswa semester pertama di Universitas Cambridge, Cavendish Laboratory. Hasil penelitian menunjukkan bahwa bentuk pertanyaan scaffolding dapat memperbaiki secara cepat kemampuan pemecahan masalah karena sebelumnya mahasiswa memiliki kesalahan matetatika pada saat menyelesaikan pemecahan masalah fisika.

\section{KESIMPULAN}

Hasil penelitian menunjukan bahwa struktur pertanyaan dapat mempengaruhi konsistensi siswa. Dampak perbedaan struktur pertanyaan yakni pada soal terikat dan soal tidak terikat dapat mempengaruhi konsistensi siswa terbukti dengan masih banyak siswa tidak konsisten pada kedua bentuk soal. Namun, pada soal tidak terikat menunjukan siswa lebih banyak tidak konsisten. Konsistensi yang dimiliki siswa masih sangatlah kurang berdasarkan struktur pertanyaan. Hal ini menyebabkan proses pemecahan masalah yang digunakan pun berbeda-beda. Oleh karena itu, dapat disimpulkan struktur pertanyaan dapat mempengaruhi konsistensi siswa dalam menyelesaikan soal sehingga dapat mempengaruhi proses pemecahan masalah siswa.

DAFTAR PUSTAKA 
[1] Prihastuti, A. (2013). Konsistensi antara Pandangan dan Prilaku Siswa Dalam Memecahkan Masalah Fisika. Skripsi pada Program Studi Pendidikan Fisika FKIP. Universitas Tadulako Palu: tidak diterbitkan.

[2] Polya. (1957). How To Solve It? A New Aspect of Mathematical Methot (2 ${ }^{\text {nd }}$ Edition). New Jersey: Princeton University Press.

[3] Tongchai, A. et al. (2011). Consistency Of Students' Conceptions Of Wave Propagation: Findings From A Conceptual Survey In Mechanical Waves. [Online]. Tersedia: http://journals.aps.org/prstper/ abstract/0.1103/PhysRev STPER7.020101. [27 September 2014].

[4] Gibson, V., Jardine, W.L. and Bateman, E. (2015). "An Investigation Into The Impact Of Question Structure On The Performance Of First Year Physics Undergraduate Student At The University Of Cambridge". European Journal of Physics. 36 045014 (17pp).

[5] Kryjevskaia, M., Stetzer, M.R. and Grosz, N. (2014). Answer First: Applying The Heuristic-Analytic Theory of Reasoning To Examinen Student Intuitive Thinking In The Context of Physics. [Online]. Tersedia: http://journals.aps.org/prstper/ abstract/10.1103/PhysRevSTPER.10.020109.[27 September 2014]. 